\title{
SUFISME DALAM HINDU DAN ISLAM
}

\author{
Afrizal El-Adzim Syahputra \\ afrizaleladzimi@gmail.com \\ Dosen STIT Sunan Giri Trenggalek
}

\begin{abstract}
Abstrak
Agama Hindu dapat digolongkan sebagai agama tertua di dunia. Agama ini awalnya tidak memilik nama. Namun seiring perkembangan zaman, agama ini kemudian dinamakan Hindu karena mayoritas pemeluknya berada di kawasan sungai Indus di India. Konsep sufi dalam Islam seringkali dikaitkan dengan keberadaan agama lain. Hal ini tidak heran memang keberadaan agama Islam yang di bawa oleh nabi Muhammad memang datang belakangan. Selain itu perluasan Islam di berbagai penjuru dunia juga mengalami asimilasi dengan kearifan lokal dan budaya setempat. Penelitian ini menyimpulkan bahwa konsep sufi di dalam Islam maupun Hindu memiliki kesamaan, akan tetapi keduanya memiliki sejarah yang mandiri. Kesufian di dalam Islam murni dari ajaran Islam, baik dari al-Qur'an maupun hadis. Sedangkan sufisme di dalam Hindu juga memiliki kemandirian ajaran, meskipun secara kebetulan ada yang sama, yaitu penggunaan tasbih dan kesederhanaan hidup.
\end{abstract}

\section{Kata kunci: Konsep Sufi, Islam-Hindu}

\section{Latar Belakang}

Sebagian orang beranggapan bahwa sufisme di dalam Islam adalah copy-paste dari ajaran Hindu. Anggapan itu tidak sepenuhnya salah. Sebab, memang ada persamaan di antara keduanya. Namun apakah dengan adanya persamaan tersebut lantas dengan mudah seseorang men-justifikasi bahwa ajaran tersebut adalah jiplakan? Hal inilah yang menjadi fokus penelitian dalam kajian ini. Jika memang ada persamaan, 
dari sisi apakah persamaan itu? Apakah lahir dari ajaran yang mandiri dari masing-masing atau hanya kebetulan sama? Jika memang ada persamaan, sejauh manakah persamaan itu?

A. Sufisme dalam Agama Hindu

Secara etimologi kata 'Hindu' berasal dari bahasa Sansekerta Siddu yang mana oleh orang-orang Persia kuno di ucapkan dengan kata 'Hindu'. Kata ini sebenarnya adalah nama sebuah daerah di India yang memiliki tujuh sungai di barat daya dan salah satu sungai tersebut adalah sungai Indus. Sehingga definisi Hindu adalah orangorang yang bertempat tinggal di bantaran sungai Indus India. Sedangkan di India sendiri, agama Hindu disebut dengan Waidika Dharma yang memiliki arti agama yang berdasarkan kitab suci Weda. ${ }^{1}$

Secara pasti sebenarnya agama Hindu tidak memiliki pendiri, begitu pula dengan kitab sucinya, Weda. Tidak diketahui secara pasti kapan agama tersebut mulai lahir dan kepada siapa kitab tersebut di wahyukan. Namun umat Hindu percaya bahwa kitab tersebut diwangsitkan sejak awal yang setara dengan yang mewangsitkannya. ${ }^{2}$

Ketidak-mampuan sejarah di dalam menguak data-data mengenai Hindu ini dapat dimaklumi, sebab agama ini awalnya tidak memiliki nama. Namun secara praktik telah dijalankan oleh orangorang India. Selain itu, agama Hindu juga sudah ada sebelum masa penulisan sejarah berkembang. Untuk itu sejarawan cukup kesulitan dalam menggali data tentang agama ini.

1. Konsep Sufi dalam Hindu

a. Vegetarianisme

Kata vegetarianisme secara bahasa terdiri dari kata vegetable dan isme. Vegetable berasal dari bahasa Ingris yang memiliki arti tumbuh-tumbuhan atau sayur-sayuran. Sedangkan bagi orang yang mengkonsumsi sayur-sayuran disebut dengan vegetarian. Kata isme memiliki arti gagasan, ide

${ }^{1}$ Mukti Ali, Agama-agama di Dunia (Yogyakarta: IAIN Sunan Kalijaga Press, 1988), 93.

2 M. Ali Imron, Sejarah Terlengkap Agama-agama di Dunia: Dari Masa Klasik Hingga Modern (Yogyakarta: IRCSoD, 2015), 70. 
atau pemikiran. Jadi, jika kata ini digabungkan memiliki arti orang-orang yang memiliki pandangan tentang memakan sayur-sayuran atau lebih spesifik orang yang tidak memakan daging jenis hewan apapun. Dalam Kamus Besar Bahasa Indonesia dijelaskan bahwa vegetarianisme memiliki arti 'Paham yang menyatakan berpantang makan makanan hewani, tetapi hanya memakan makanan nabati. ${ }^{3}$

Dalam agama Hindu terdapat konsep sufi tentang vegetarianisme yang di atur dalam kitab Bhagavadgita dan Bhagavata Purana. Ajaran ini juga memiliki keterkaitan dengan konsep abimsa ${ }^{4}$. Itulah sebabnya banyak umat Hindu yang mengikuti vegetarianisme demi menghormati bentuk kehidupan yang tingkatannya tinggi. Namun yang menjadi persoalan adalah konsep ini tidak dipraktikkan oleh seluruh orang Hindu. Sebagian dari mereka juga tetap mongkonsumsi daging.

Dalam agama Hindu dampak mengkonsumsi makanan memiliki efek yang signifikan karena hal ini akan berdampak kepada bersihnya hati. Oleh karena itu, murninya makanan begitu diprioritaskan. Mereka meyakini bahwa dalam makanan memiliki tiga kualitas sifat (triguna) yang umum yaitu kesucian (satwam) semangat (rajas) dan kelambanan (tamas). Karena itu umat Hindu dianjurkan untuk mengkonsumsi makanan yang bisa membersihkan hati, yaitu dengan cara vegetarianisme.

Menurut Chandogya Upanisad 'Pemikiran terbentuk dari makanan. Jumlah makanan yang dimakan, akan menjadi kotoran. Komponen terbaik dari makanan akan membentuk tubuh dan makanan yang terbaik serta komponen yang terhalus akan membentuk pikiran kita.' Dengan ungkapan lain bisa dikatakan bahwa makanan memiliki pengaruh yang cukup besar terhadap tubuh dan perilaku seseorang. Hal ini

${ }^{3}$ Team, Kamus Besar Bahasa Indonesia, Digital.

4 Ajaran agama Hindu dan Budha untuk tidak menyakiti makhluk apapun dan menghindari kekerasan. 
didasarkan pada pengalaman para Resi ${ }^{5}$ Hindu. Lalu mereka membagi makanan menjadi tiga kategori: sattvika (murni), rajasika (berenergi), dan tamasika (buruk).

Makanan yang tergolong sattvika (murni) dapat memberikan ketenangan dan kesucian pada pikiran. Sedangkan jenis makanan yang termasuk dalam ketegori ini adalah jenis sayur-sayuran, kacang-kacangan, biji-bijian dan jenis-jenis tumbuhan yang lain. Sedangkan makanan yang berjenis rajasika (berenergi) dapat menyebabkan kegelisahan seperti bawang, merica, bumbu serta makanan asam dan pahit. Sementara makanan yang dikategorikan tamasika (buruk) adalah daging, minuman beralkohol dan makanan basi.

Oleh sebab itu, aliran dalam Hinduisme menganjurkan penganutnya menjadi vegetarianisme. Sebagian juga melarang pengorbanan terhadap hewan. Namun yang perlu di catat adalah meskipun sebagian pemeluk Hindu ada yang mengkonsumsi daging, mereka tidak mau mengkonsumsi daging sapi. Sebab, dalam agama Hindu, sapi dipercaya sebagai pengasuh manusia serta merupakan figur keibuan. Mereka juga menganggapnya sebagai simbol kasih yang tak bersyarat. Oleh sebab itu, penyembelihan sapi dilarang secara resmi di hampir seluruh negara bagian di India. ${ }^{6}$

b. Pertapaan

Tapa secara bahasa memiliki arti 'bertarak, menahan hawa nafsu berpantang dan sebagainya ${ }^{, 7}$ orang yang bertapa memiliki tujuan untuk mengendalikan energi agar terpusat sehingga dapat digunakan untuk suatu tujuan. Dalam agama Hindu, istilah bertapa disebut dengan sanyasa. Penganut agama Hindu masih banyak yang melakukan pertapaan. Hal ini mereka lakukan sebagai upaya untuk mencapai kelepasan

\footnotetext{
${ }^{5}$ Petapa atau orang suci.

${ }^{6}$ M. Ali Imraon, Sejarah Terlengkap ..., 112-113.

7 Team, Kamus Besar Bahasa Indonesia, Digital.
} 
(moksa) ataupun untuk mencapai spiritual lainnya. Orang yang bertapa memiliki komitmen untuk hidup sederhana, tidak berhubungan dengan keramaian, tidak berhubungan seksual, tidak mencari harta benda, serta berkontemplasi ${ }^{8}$ tentang Tuhan.

Dalam agama Hindu, orang yang mampu melepaskan diri dari ketergantungan terhadap duniawi, mereka akan mendapatkan tempat yang istimewa di mata masyarakat. Karena dalam pandangan mereka, orang tersebut mampu menahan egoisme dan duniawinya sehingga menjadi inspirasi bagi orang lain untuk berjuang dalam mengendalikan pikiran.

Untuk melakukan pertapaan, mereka memilih tempattempat yang di anggap sakral atau suci seperti kuil, biara dan sebagainya. Ada pula yang berkelana dari satu tempat ke tempat yang lain. Bagi umat Hindu awam, mereka menyediakan makanan dan kebutuhan untuk para pertapa itu dan mereka cukup bangga dengan hal tersebut karena merupakan jasa yang sangat besar. Sementara dari sisi orang yang bertapa, mereka menerimanya dengan senang hati karena hal itu di anggap sebagai sebuah bentuk penghormatan.

B. Wahyu dan Muhammad

Secara etimologi, kata 'Islam' berasal dari bahasa Arab aslama yuslimu islaman yang memiliki arti 'selamat, patuh dan tunduk'. Sedangkan secara terminologi Islam memiliki makna orang yang patuh dan tunduk kepada Allah swt. Dengan pengertian ini, maka makna Islam adalah tidak dibatasi oleh waktu dan tempat. Siapapun orang yang patuh dan tunduk kepada Allah baik sebelum dan sesudah datangnya Nabi Muhammad, maka ia seorang muslim. Dengan demikian, nabi-nabi terdahulu seperti nabi Adam, Musa Ibrahim dan yang lainnya adalah muslim.

Dalam catatan sejarah, orang yang membawa risalah agama Islam adalah Nabi Muhammad saw.Nabi lahir di kota Makkah al-

${ }^{8}$ Renungan dengan kebulatan pikiran atau perhatian penuh. 
Mukarramah pada tanggal 20 April tahun 571 M. Ayahnya bernama Abdullah dan ibunya bernama Aminah. Namun pada saat Muhammad masih dalam kandungan, ayahnya meninggal dunia. Sedangkan ibunya juga meninggal dunia pada saat Nabi masih berumur 7 tahun.

Kebiasaan nabi Muhammad memang berbeda dengan kebiasaan orang-orang Arab pada umumya. Dikala itu, degradasi moral dapat dikatakan begitu parah. Umumnya orang-orang suka minum-minuman keras, berjudi, menyembah berhala hingga mengubur hidup-hidup bayi perempuan yang baru lahir. Kebiasaan ini tidak terjadi pada diri Muhammad. Ia termasuk orang yang jujur dan bertanggungjawab dalam menjalankan amanat orang lain. Terbukti pada usia yang relatif muda, ia dipercaya Khadijah untuk menjalankan dagangannya keluar negeri, Syam. Kala itu, karena keuntungan yang didapat dari perdagangan begitu banyak, akhirnya dikemudian hari Muhammad dipercaya kembali menjalankan dagangannya.

Setelah Khadijah tahu karakter Muhammad, akhirnya ia jatuh hati dan memutuskan untuk menikah dengannya. Khadijah adalah janda dua kali yang sudah berumur 40 tahun sedangkan Muhammad adalah pemuda yang masih perjaka umur 25 tahun. Pernikahan keduanya mendapatkan kebahagiaan dan dikaruniai enam orang anak yaitu: Qasim, Abdullah, Zainab, Ruqayyah, Ummi Kulsum dan Fatimah.

Pada saat Nabi Muhammad berusia 35 tahun, Ka’bah di renovasi. Kala itu Ka'bah adalah tempat ibadah para peziarah dari berbagai penjuru dunia sekaligus tempat sentral perdagangan dari dalam maupun luar negeri. Oleh sebab itu, Ka'bah adalah icon kota Makkah. Pada saat peletakan batu pertama banyak para pemimpin kabilah yang berebut ingin meletakkan batu itu. Sehingga hampir terjadi perkelahian. Namun ketika perselisihan mencapai puncaknya, ada salah seorang bernama Abu Umaiyah bin Mughirah al-Makzumi

9 Muhammad Sa'id Ramadhan al-Buthy, Sirah Nabawiyah, Analisi Ilmiah Manbajizyab: Sejarah Pergerakan Islam di Masa Rasulullah saw. (Jakarta: Rabbani Press, 2010), 31. 
yang mengusulkan agar persolan tersebut diserahkan kepada orang yang pertama kali memasuki Masjidil Haram melalui Bāb al-Safa. Usul itu diterima dan ternyata pada hari itu, orang yang pertama kali masuk melalui pintu itu adalah nabi Muhammad.

Setelah sosok orang yang layak untuk meletakkan hajar aswad sudah ketemu, Nabi Muhammad meminta sehelai kain yang lebar untuk dibentangkan. Masing-masing kepala suku (kabilah) diminta untuk memegang kain tersebut dan Muhammad-lah yang kemudian meletakkan hajar aswad itu. Keputusan ini benar-benar mampu melerai perselisihan dari berbagai pihak bahkan melegakan banyak pihak. Sebab mereka merasa satu sama lain masih diikut-sertakan dalam peletakan hajar aswad tersebut. peristiwa inilah yang menjadikan Muhammad mendapatkan julukan al-Amin (orang yang dapat dipercaya).

Setelah Nabi Muhamad berusia 40 tahun, ia menerima wahyu untuk pertama kalinya yaitu surat al-'Alaq ayat 1-5 hingga akhir hayatnya wahyu tersebut sempurna. Wahyu ini dinamakan al-Qur'an yang memiliki arti 'bacaan'. Seluruh peribadatan umat Islam sepenuhnya berdasar kepada dua hal, yaitu al-Qur'an sebagai wahyu Tuhan dan hadis Nabi Muhammad saw. termasuk praktik-praktik sufi yang mengacu pada keduanya (al-Qur'an dan hadis).

\section{Sufisme dalam Islam}

Secara esensial praktik-praktik sufi dalam Islam memang memiliki kemiripan dengan agama lain. Misalnya penggunaan Tasbih, 'uzlah, dzikir berlama-lama dan sebagainya. Berikut adalah rincian dari beberapa aspek tasawuf dalam Islam.

1. Penggunaan tasbih

Kata Tasbih sebenarnya di ambil dari bahasa Arab sabbaha yasbạ̣u tasbị̣an yang memiliki arti 'menyucikan'. Kata ini digunakan oleh umat muslim untuk 'mensucikan asma Allah'. Namun secara praktik, tasbih adalah alat yang digunakan oleh umat Islam untuk menghitung jumlah dzikir.

Perhitungan dzikir dengan menggunakan tasbih secara otomatis lebih mudah dibandingkan dengan menggunakan jari- 
jari. Sebab dalam berbagai tarekat yang ada dalam Islam, jumlah dzikir atau wirid cukup banyak. Ada yang seratus kali setiap selesai shalat fardhu dan ada pula yang dengan hitungan tertetntu hingga mencapai ribuan. Perhitungan seperti ini akan sangat membantu umat muslim jika ia menggunakan tasbih sebagai alat untuk menghitung.

Pada umumnya, tasbih berjumlah 33 biji di kalikan tiga, sehingga jumlahnya mencapai 99. Perhitungan ini biasanya disesuaikan dengan jumlah bacaan dzikir setelah shalat fardhu. Bacaan subḥanallăh di ulang sebanyak 33 kali. Bacaan Alhamdulillăh di ulang sebanyak 33 kali dan bacaan Allähu Akbar di ulang sebanyak 33 kali. Jika di jumlahkan ketiga bacaan tersebut, maka menjadi 99 bacaan. Angka ini juga sekaligus memiliki filosofi Asma' al-Husna yang ada 99 dan apabila orang yang dzikir tersebut berkeinginan menggunakan hitungan bulat 100, maka pada setiap akhir hitungan 33 ada pembatas kecil untuk membedakan bacaan dzikirnya. Sedangkan setelah hitungan ke-99 terdapat pembatas besar sebagai pertanda bahwa hitungan dzikir seseorang mencapai angka 100. Angka-angka inilah yang memudahkan orang untuk mencapai hitungan tertentu sesuai yang di inginkan.

Sedangkan dasar dari semua dzikir itu sudah cukup banyak baik dalam al-Qur'an maupun hadis Nabi, baik yang berkaitan dengan bacaan Subhānalläh, Alhamdulillāh, Alläbu Akbar, Là ilăha illa Allāh dan sebagainya. Secara umum, perintah untuk berdzikir terdapat dalam al-Qur'an surat al-Insān [76]: 25 sebagai berikut:

$$
\text { وَاذْكُرِ اسْمَ رَبِّكَ بُكْرَةً وَأَصِيلاً }
$$

'Dan sebutlah nama Tuban-mu diwaktu pagi dan petang'.

Mengenai bacaan subhānallāh (Maha Suci Allah) terdapat dalam surat al-Fath [48]: 9 sebagai berikut:

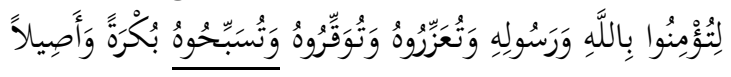


'Supaya kamu sekalian beriman kepada Allah dan rasul-Nya, menguatkan (agama)-Nya, Mengagungkannya dan bertasbiblab diwaktu pagi dan petang.'

Dasar bacaan dzikir al-hamdulillāh (segala puji bagi Allah) terdapat dalam surat al-Taghābun [64]: 1 sebagai berikut:

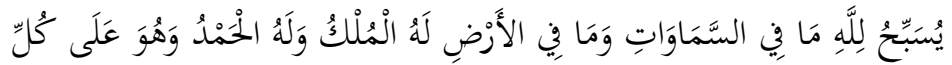
شَيْيٍ قََِيرٌ

'Bertasbih kepada Allah apa yang ada di langit dan apa yang ada di bumi; hanya Allab-lah yang memiliki semua kerajaan dan semua pujian dan Dia Maha Kuasa atas segala sesuatu.'

Dasar bacaan Allähu Akbar adalah terdapat dalam surat al-Ankabūt [29]: 45 sebagai berikut:

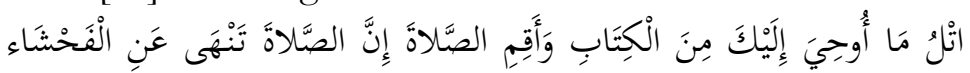

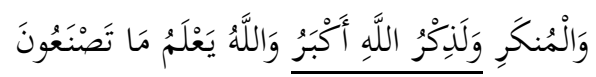

'Bacalah apa yang telah diwabynkan kepadamu, yaitu al-Kitab (al-Qur'an) dan dirikanlah shalat. Sesunggubnya shalat itu dapat mencegah perbuatan keji dan munkar. Dan sesunggubnya mengingat Allah lebih besar. Allah Maha Mengetabui apa yang kamu kerjakan.'

Sedangkan dasar bacaan Là ilāha illa Allāh adalah surat Muḥammad [47]: 19 sebagai berikut:

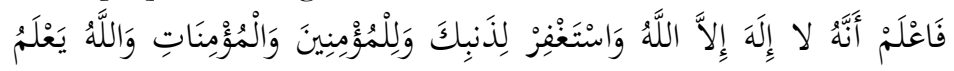

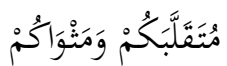

'Ketahuilah babwasannya tiada tuhan selain Allah dan mohonlah ampunan bagi dosamu dan terbadap orang-orang mukmin lakilaki dan perempuan. Allah Mengetabui tempat kamu berusaba dan dan tempat kamu tinggal.'

Sementara hadis yang memperkuat ayat di atas adalah had is riwayat $\mathrm{Abu}$ Dâwud nomor 3118 sebagai berikut: 


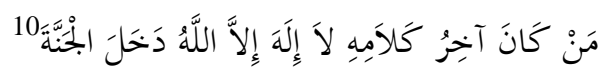

'Barangsiapa di akbir bidupnya mengucapkan Là ilāha illa Allāh maka masuk surga.'

Dari beberapa dasar melalui al-Qur'an dan hadis di atas dapat disimpulkan bahwa, substansi dzikir dalam Islam memiliki kemandirian tanpa adanya intervensi dari agama lain meskipun media yang digunakannya memiliki persamaan dengan agama Hindu.

2. U₹lah

Secara bahasa kata 'u₹lah' memiliki arti 'menyendiri'. Kata ini lazim digunakan di dunia tasawuf sebagai orang yang menjauhkan diri dari hiruk-pikuk dunia. Biasanya seorang sufi memilih cara ini agar ia bisa berkonsentrasi dalam beribadah kepada Allah.

Sebenarnya 'u₹lah tidak selalu identik dengan menyendiri di tempat yang sepi seperti di goa atau di hutan. Menyendiri bisa juga dilakukan di rumah sendiri namun tidak banyak melakukan kegiatan-kegiatan yang bersifat duniawi. Praktik ini memang pernah dilakukan oleh Nabi Muhammad saw. pada saat beliau menerima wahyu yang pertama, tepatnya di goa Hira'.

Namun yang perlu diperhatikan adalah praktik 'uzlah yang dilakukan oleh Nabi disebut dengan tahannuth dari singkatan kata tark al-hanath (meninggalkan dosa). Jadi tujuan utama dari u乏lah yang dilakukan oleh Nabi adalah meninggalkan dosa-dosa apabila ia berbaur dengan masyarakat yang kala itu sudah abmoral, bukan hendak meninggalkan masyarakatnya atau meninggalkan ibadah wajib. Hal ini dilakukan semata-mata ingin menjauhkan diri dari dosa karena dikhawatirkan akan terjerumus apabila tidak menjauh.

Oleh sebab itu, praktik uzlah yang dilakukan oleh para kaum sufi adalah untuk menghindari dosa apabila ia terlalu lama

${ }_{10}$ Abū Dāwud Sulaimān bin al-Ash'ath al-Sjastāni, Sunan Abī Dānud (Beirut: Dār alKutub al-'Arabi, tt), 3118. 
bersinggungan dengan dunia. Selain itu praktik 'u₹lah yang dilakukan tidak harus ditempat yang jauh dari keramaian, sebatas ia bisa lebih fokus untuk beribadah, disitu sudah cukup untuk dikatakan sebagai 'u₹lah.

\section{Pola Hidup Sederhana}

Agama dinilai berhasil apabila mampu menanamkan nilai religiositas terhadap pemeluknya. Bagitu pula dengan Islam. Sejak awal masa pemerintahan Nabi saw. Islam sudah menanamkan nilai religiositas. Hal ini dapat dilihat dari gaya hidup Nabi.

Andaikata hari ini ada seorang kepala negara, semisal presiden atau raja, apakah ada yang menerapkan pola hidup sebagaimana Nabi? rumah yang sederhana, bahkan alasnya tidur dari pelepah kurma. Padahal pada waktu itu sudah banyak karpet bagus dari Persia. Andaikata Nabi mau memakai atau membelinya, tentu Nabi mampu. Tetapi hal ini tidak dilakukan. Sebab, Nabi lebih mementingkan nilai-nilai religiositas daripada kepentingan duniawi.

Andaikata hari ini ada seorang kepala hakim agung, sekelas Mahkamah Agung atau Mahkamah Konstitusi, apakah ada yang menerapkan hidup sebagaimana Nabi, dengan kesederhanaannya?. Apakah sekarang ada seorang panglima militer, sekelas Panglima TNI atau Polri yang hidup dengan kesederhanaan sebagaimana Nabi?. Andaikata ketiga jabatan ini berkumpul kepada satu orang, kepala pemerintah, kepala militer, kepala bidang hukum, tertumpu hanya kepada satu sosok, tentu pola hidupnya akan bermewah-mewahan. Orang baru mencapai jabatan DPR saja hidupnya sudah sedemikian mewah, apalagi jika tiga jabatan tertinggi di negeri ini hanya di pegang satu orang.

Walalupun semua jabatan itu tertumpu kepada satu sosok, Nabi, akan tetapi pola kehidupannya sungguh di luar dugaan. Ia adalah sosok yang sangat sederhana, hingga makan-minum untuk kebutuhan sehari-haripun kadang tiada. Jika tidak ada yang di buat untuk sarapan, Nabi akan puasa di hari itu juga. Begitulah sosok pola kehidupan Nabi yang sangat sederhana sehingga menjadi inspirasi banyak orang untuk mencontohnya. Tak 
terkecuali oleh para kaum sufi. Jadi, kesederhanaan yang dicontoh oleh kaum sufi bukanlah ada pengaruh dari agama lain atau dari budaya lain di luar Islam, akan tetapi memang sosok Nabi yang menjadi suri tauladan. Hal ini sesuai dengan perintah yang ada di dalam al-Qur'an:

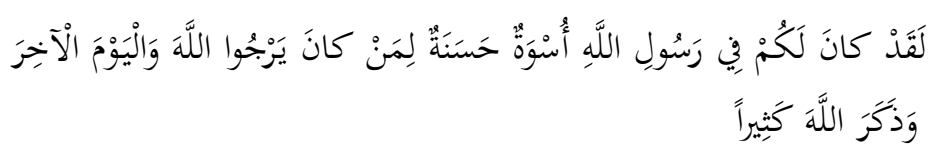

Telah ada pada diri Rasūl Allāh suri tauladan yang baik bagi orang yang mengharapkan (rahmat) Allah dan hari akhir dan selalu memperbanyak dịikir kepada Allah. (QS. Al-Aḥzāb [33]: 21).

\section{Kesimpulan}

Konsep sufi dalam Hindu secara garis besar ada dua hal, yaitu vegetarianisme dan pertapaan. Vegetarianisme adalah pandangan bahwa makanan memiliki pengaruh yang signifikan terhadap prilaku seseorang. Oleh sebab itu, para Resi Hindu membagi jenis makanan menjadi tiga bagian: makanan yang murni seperti tumbuh-tumbuhan, makanan yang berenergi seperti bawang dan bumbu-bumbu serta makanan yang buruk seperti daging dan minuman beralkohol. Dengan demikian umat Hindu dianjurkan untuk mempraktikkan konsep ini. Konsep sufi kedua adalah bertapa. Konsep ini memiliki arti menjauhkan diri dari kesibukan duniawi, tidak menikah, tidak memburu harta benda, hidup sederhana dan fokus ibadah di dalam tempat suci.

Konsep sufi dalam Islam dari segi ajaran dzikir seperti pembacaan subhanallăh, al-ḥamdulillăh dan là ilāha illăh dan sebagainya memang memiliki dasar dari al-Qur'an dan hadis. Dengan demikian konsep sufi dalam Islam dapat dikatakan murni dari ajaran Islam, tanpa adanya intervensi dari ajaran agama lain. Sedangkan media yang di gunakan untuk berdzikir menggunakan tasbih. Alat ini memang digunakan dalam agama Hindu-Budha. Namun bacaannya 
yang berbeda dengan Islam. Penggunaan tasbih hanya sebagai alat untuk menghitung dzikir, bukan substansinya. Sebab andai tidak ada tasbih, umat Islam juga masih bisa menggunakan media yang lain.

Sedangkan sisi persamaannya dengan sufi dalam Islam adalah penggunaan tasbih, konsep sederhana, menjauhkan diri dari hirukpikuk dunia dan lebih fokus ibadah kepada Tuhan. Dari beberapa persamaan tersebut yang menjadikan pembedanya adalah dari sisi sumber. Sebab, sumber ajaran dalam praktik sufi adalah tetap kepada hadis nabi bukan karena pengaruh agama yang lain. 
Spiritualis, vol. 4, no. 1, Maret 2018|27

\section{DAFTAR PUSTAKA}

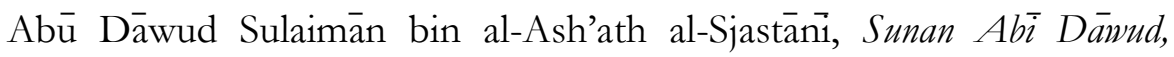
Beirut: Dār al-Kutub al-'Arabi, tt.

Ebta Setiawan, Kamus Besar Bahasa Indonesia, Digital, 2011.

M. Ali Imron, Sejarah Terlengkap Agama-agama di Dunia: Dari Masa Klasik Hingga Modern, Yogyakarta: IRCSoD, 2015.

Muhammad Sa'id Ramadhan al-Buthy, Sirah Nabawiyah, Analisi Ilmiah Manhajiyyah: Sejarah Pergerakan Islam di Masa Rasulullah saw. Jakarta: Rabbani Press, 2010.

Mukti Ali, Agama-agama di Dunia, Yogyakarta: IAIN Sunan Kalijaga Press, 1988.

Team Pusat Bahasa Depatemen Pendidikan Nasional, Kamus Besar Bahasa Indonesia, Jakarta: Balai Pustaka, 2008. 